\title{
IN HOUSE TRAINING PENYUSUNAN ADMINISTRASI PEMBELAJARAN UNTUK MENINGKATKAN KOMPETENSI GURU MTS INDOTEC KENDARI
}

\author{
Djusni Arief \\ Departemen Agama Kota Kendari, Sulawesi Tenggara) \\ Korespondensi :djusniarief448@gmail.com
}

\begin{abstract}
Abstrak.
Telah dilakukan penelitian Tindakan kelas pada Guru MTs Indotec Kendari dalam kegiatan In-House Training penyusunan administrasi pembelajaran sebagai Penelitian Tindakan Kepengawasan untuk meningkatkan komptetnsi guru. Dengan adanya kegiatan In-House Training penyusunan administrasi pembelajaran diharapkan semua guru memiliki administrasi pembelajaran yang lengkap dan mengaplikasikannya dalam proses pembelajaran sehingga proses pembelajaran yang dilakukan akan lebih terarah karena tujuan pembelajaran, materi yang akan diajarkan, metode dan penilaian yang akan digunakan telah direncanakan dengan berbagai pertimbangan. Subjek dalam penelitian ini adalah guru-guru MTs INDOTEC Kendari sejumlah 13 orang guru. Penelitian In House Training ini terdiri dari dua siklus dan tiap siklus terdiri dari empat tahap yaitu perencanaan, pelaksanaan,pengamatan dan refleksi. Hasil dari penelitian ini menunjukkan bahwa pelaksanaan in house training dapat meningkatkan kompetensi guru di dalam menyusun administrasi pembelajaran di MTs INDOTEC Kendari. Pada siklus I kompetensi guru di dalam menyusun administrasi pembelajaran adalah 53,37 dengan 50\% guru yang telah dapat menyusun administrasi pembelajaran dengan baik dan benar. Pada siklus II kompetensi guru di dalam menyusun administrasi pembelajaran adalah 93,27 dengan $100 \%$ guru yang telah dapat menyusun administrasi pembelajaran dengan baik dan benar.
\end{abstract}

Kata kunci: InHouse Training, Kompetensi Guru,Administrasi Pembelajaran.

\section{PENDAHULUAN}

Salah satu masalah pokok yang dihadapi MTs INDOTEC adalah hasil belajar yang cenderung masih rendah, kurangnya kemampuan siswa dalam menelaah soal-soal yang diberikan oleh guru, baik pada ulangan harian, ulangan tengah semester maupun ulangan akhir semester menurut data yang diinventarisir oleh bagian kurikulum masih cenderung rendah dan belum memuaskan. Rata-rata siswa yang dapat tuntas sesuai KKM berkisar antara 40 $50 \%$, sedangkan sisanya untuk 
menuntaskan harus menempuh remedial. Keberhasilan sebuah pembelajaran setidaknya dipengaruhi oleh 5 komponen kunci, yaitu: (1) Guru, (2) Sumber dan Media Belajar,

Lingkungan, (4) Siswa dan (5) proses pembelajaran. Guru dalam pembelajaran memiliki peran yang sangat strategis karena akan berkaitan dengan pengelolaan 4 komponen kunci lainnya. Bahkan dalam konsep tentang sumber belajar yang ditulis oleh Sudjarwo dikutip oleh (Rahmat Saripudin,2008) guru dapat dikategorikan sebagai sumber belajar.

Berdasarkan

observasi pembelajaran pada MTs Indotec diperoleh data kurangnya kemampuan guru dalam menyusun pembelajaran yang baik, umumnya guru menyusun perangkat pembelajaran tidak sesuai dengan rambu-rambu yang telah ditetapkan. Untuk mewujudkan guru yang profesional yang mampu meningkatkan kompetensi dan mutu lulusan, maka kami selaku pengawas pembina mendorong pengelola madrasah untuk merancang program-program dan kegiatan yang mengarah pada peningkatan mutu guru MTs INDOTEC dan salah satunya melalui In-House Training penyusunan administrasi pembelajaran. Hal ini mendesak dilakukan karena dari angket yang diberikan kepada guru untuk mengetahui respon guru terhadap pentingnya memiliki administrasi pembelajaran $75 \%$ menyatakan sangat setuju dan $25 \%$ setuju artinya seluruh guru menyatakan setuju/sepakat untuk memiliki administrasi pembelajaran. Lebih lanjut dari angket juga terungkap tentang perlunya diadakan InHouse Training dengan data seluruh guru menghendaki adanya In-House Training penyusunan administrasi pembelajaran. Selain itu angket juga mengungkap bahwa guru memiliki kemauan yang kuat untuk memiliki administrasi pembelajaran dengan data $73 \%$ menjawab sangat setuju dan $26 \%$ menjawab setuju yang artinya seluruh guru menyatakan jika diadakan InHouse Training maka mereka akan mengikuti dengan sungguhsungguh dan akan mengaplikasikannya dalam kegiatan pembelajaran.

Guru merasa bahwa pengalaman mengajarnya masih minim pada mata pelajaran yang 
diajarkan, latar belakang pendidikan tidak begitu sesuai dengan mata pelajaran yang diajarkan dan pengetahuan tentang penyusunan kelengkapan mengajar masih kurang.

Lebih lanjut dari angket juga terungkap tentang perlunya diadakan In-House Training dengan data $100 \%$ sangat setuju yang mengindikasikan bahwa seluruh guru menghendaki adanya In-House Training penyusunan kelengkapan mengajar.

Atas dasar hal tersebut di atas maka MTs INDOTEC menyatakan sangat perlu mengadakan In-House Training. Dengan adanya kegiatan In-House Training penyusunan administrasi pembelajaran diharapkan semua guru memiliki administrasi pembelajaran yang lengkap dan mengaplikasikannya dalam proses pembelajaran sehingga proses pembelajaran yang dilakukan akan lebih terarah karena tujuan pembelajaran, materi yang akan diajarkan, metode dan penilaian yang akan digunakan telah direncanakan dengan berbagai pertimbangan.

\section{METODOLOGI PENELITIAN}

Penelitian ini dilaksanakan di MTs INDOTEC Kendari TP. 2018/2019 tanggal 22 Januari sampai dengan tanggal 23 Februari tahun 2019. Selama 4 (empat) minggu dengan subjek penelitian adalah guru dengan jumlah sampel 13 orang guru.

Penelitian ini dilaksanakan dalam 2 siklus. Tiap siklus terdiri dari empat tahapan yaitu tahap persiapan, tahap pelaksanaan tindakan (Inhouse-training), dan tahap pengumpulan data dan tahap analisis data (refleksi).

Adapun langkah-langkah dalam penelitian ini adalah sebagai berikut:

\section{Tahap Perencanaan}

a. Menyiapkan daftar guru

b. Menyiapkan lembar observasi guru

c. Menyiapkan evaluasi in house training guru

\section{Tahap Pelaksanaan}

Pada tahap pelaksanaan, dilakukan training ssuai dengan perencanaan

\section{Tahap Observasi}

Pada tahap ini, peneliti mengamati aktivitas guru selama proses pelatihan. Tahap observasi yang dilakukan dalam penelitian ini dengan menggunakan lembar observasi yang telah disediakan.

\section{Tahap Refleksi}

Tahap refleksi meliputi proses analisis hasil pembelajaran dan penyusunan rencana perbaikan 
untuk program in house training berikutnya.
a. Mencatat hasil pengamatan
b. Mengevaluasi hasil pengamatan
c. Menganalisis
tingkat pemahaman guru di dalam mengikuti program in house training.
d. Membuat perbaikan tindakan untuk program in house training berikutnya.

\section{HASIL DAN PEMBAHASAN}

\begin{tabular}{llr}
\multicolumn{2}{c}{ Langkah awal } & $\begin{array}{r}\text { yang } \\
\text { dilakaukan dalam }\end{array}$ \\
peniatan & \\
pentian ini adalah & dengan
\end{tabular} memberikan angket yang berkaitan dengan pentingnya administrasi pembelajaran bagi guru. Adapun hasil yang diperoleh dari dari analisis data angket, diperoleh data bahwa bahwa 76,9\% guru menyadari bahwa sebagai seorang guru sangat penting memiliki administrasi pembelajaran sebelum melaksanakan proses pembelajaran dan $23,1 \%$ menyatakan penting memiliki administrasi pembelajaran. Hal tersebut berarti secara keseluruhan Guru MTs INDOTEC menyatakan penting untuk memiliki administrasi pembelajaran.

Hal ini sangatlah beralasan karena dengan memiliki administrasi pembelajaran yang baik sangat membantu kelancaran dalam proses pembelajaran. Selain itu dengan administrasi pembelajaran akan memberi kesempatan bagi guru sebagai pendidik untuk merancang pembelajaran sesuai dengan kebutuhan peserta didik, kemampuan peserta didik dan fasilitas yang dimilki sekolah. Demikian pula dengan memiliki administrasi pembelajaran proses pembelajaran yang dilakukan akan lebih terarah, karena tujuan pembelajaran, materi yang akan diajarkan, metode dan penilaian yang digunakan telah dirancang dengan berbagai pertimbangan.

Tabel 1. Ketidaksesuaian mata pelajaran yang diajarkan dengan latar belakang pendidikan guru MTs INDOTEC Kendari

\begin{tabular}{lllc}
\hline No. & Alternatif Jawaban & Jumlah & $\mathbf{\%}$ \\
\hline 1 & Sangat Setuju & (1 orang) & 7,7 \\
2 & Setuju & $(1$ orang) & 7,7 \\
3 & Cukup Setuju & (2 orang) & 15,4 \\
4 & Tidak Setuju & $(9$ orang) & 69,2 \\
5 & Sangat TidakSetuju & - & 0,00 \\
\cline { 2 - 3 } & & & 100 \\
\hline
\end{tabular}


Berdasarkan Tabel 1 diatas diperoleh data bahwa $69.2 \%$ guru yang merasa mata pelajaran yang diajarkan sesuai dengan latar belakang pendidikannya. $7.7 \%$ ragu-ragu hal ini mungkin Guru merasa mata pelajaran yang diajarkan memang tidak sesuai dengan latar belakang pendidikannya namun mereka merasa mampu mengajarkan mata pelajaran yang diajarkan mungkin karena mata pelajaran yang diajarkan tersebut masih satu rumpun dengan latar belakang pendidikannya. Selebihnya menjawab setuju yang berarti sekitar $7.7 \%$ merasa mengajar tidak sesuai dengan latar belakang pendidikannya.

Tabel 2. Tanggapan guru terkait dengan pengalaman mengajar

\begin{tabular}{llc}
\hline No. & $\begin{array}{l}\text { Alternatif } \\
\text { Jawaban }\end{array}$ & $\mathbf{\%}$ \\
\hline 1 & SangatSetuju & 0,00 \\
\hline 2 & Setuju & 33,3 \\
\hline 3 & CukupSetuju & 22,3 \\
\hline 4 & TidakSetuju & 44,4 \\
\hline 5 & Sangat TidakSetuju & 0,00 \\
\hline & & 100 \\
\hline
\end{tabular}

Dari tabel tersebut diatas dapat diartikan bahwa $44.4 \%$ menyatakan tidak setuju kalau pengalaman mengajarnya dikatakan kurang, dengan kata lain $44.4 \%$ tersebut Guru merasa sudah berpengalaman dalam mengajar sedangkan sisanya $55.6 \%$ Guru merasa dirinya belum berpengalaman mengajar. Hal ini dikarenakan mungkin karena umumya mereka belum lama mengabdikan diri sebagai guru dan juga beberapa diantaranya belum pernah mengikuti pembimbingan penyusunan aministrasi pembelajaran.

Tabel 3. Tanggapan guru terkait dengan pengalaman pelatihan

\begin{tabular}{lll}
\hline No. & $\begin{array}{l}\text { Alternatif } \\
\text { Jawaban }\end{array}$ & \% \\
\hline 1 & SangatSetuju & 90 \\
\hline 2 & Setuju & 10 \\
\hline 3 & CukupSetuju & 0,00 \\
\hline 4 & TidakSetuju & 0,00 \\
\hline 5 & $\begin{array}{l}\text { Sangat } \\
\text { TidakSetuju }\end{array}$ & 0,00 \\
\hline & & 100 \\
\hline
\end{tabular}

Tabel diatas mengindikasikan bahwa 90\% guru merasa sangat setuju diadakannya kegiatan In-House Trainiing Penyusunan administrasi pembelajaran hal ini terjadi karena sebagian besar guru belum pernah mengikuti kegiatan pelatihan sehingga mereka sangat membutuhkan pengembangan kompetensi, dan sisanya $10 \%$ menyatakan setuju diadakan In- 
House Training penyusunan administrasi pembelajaran, Dengan demikian dapat dikatakan bahwa semua guru MTs INDOTEC mengharapkan adanya In-House Training penyusunan administrasi pembelajaran. Hal ini mungkin dikarenakan sebagian besar guru menyadari bahwa dirinya belum memiliki administrasi pembelajaran, merasa pengalaman mengajarnya masih kurang serta mata pelajaran yang diajarkan kurang sesuai dengan latar belakang pendidikannya sehingga masih kesulitan dalam menyusun administrasi pembelajaran dan merasa perlu untuk meningkatkan kompetensi pedagogiknya.

Tabel 4. Motivasi Guru dalam Menyusun Administrasi pembelajaran

No. Alternatif $\quad \%$

Jawaban

\begin{tabular}{lll}
\hline 1 & SangatSetuju & 73 \\
\hline 2 & Setuju & 26 \\
\hline 3 & CukupSetuju & 0,00 \\
\hline 4 & TidakSetuju & 0,00 \\
\hline 5 & $\begin{array}{l}\text { Sangat } \\
\text { TidakSetuju }\end{array}$ & 0,00 \\
\hline & & 100 \\
\hline
\end{tabular}

Dari table tersebut diatas $100 \%$ Guru memiliki motivasi yang tinggi untuk mengikuti InHouse Training dan memiliki keinginan yang kuat untuk membuat administrasi pembelajaran bahkan akan menggunakan administrasi pembelajaran tersebut sebagai penunjang proses pembelajaran. Hal ini berarti seluruh guru MTs INDOTEC menyadari pentingnya memiliki administrasi pembelajaran. Dengan demikian In-House Training penyusunan administrasi pembelajaran memang perlu dilakukan dan mendapat dukungan yang kuat dari para guru.

\section{A. Hasil Kegiatan pada Siklus 1}

Hasil analisis pada siklus 1 hampir seluruh guru memiliki kelengkapan administrasi pembelajaran sangat kurang yakni dibawah $70 \%$.

Administrasi pembelajaran yang paling banyak terselesaikan pada siklus 1 adalah Jadwal tatap muka, Analisis Kalender Pendidikan, Pengembangan Silabus, Pemetaan SK,KD, dan Prota (Program Tahunan) yaitu sebesar $100 \%$.

Selain data seperti telah dijelaskan diatas, terdapat satu data yang menggambarkan bahwa ada seorang guru yang baru menyelesaikan administrasi pembelajaran hanya $37,50 \%$. Dari 13 komponen administrasi 
pengajaran, hanya 6 komponen

yang mampu dipenuhi. 
Tabel 5: Hasil In-House Training Tahap 1

\begin{tabular}{|c|c|c|c|c|c|c|c|c|c|c|c|c|c|c|c|c|c|c|c|c|}
\hline \multirow{2}{*}{ No } & \multirow{2}{*}{$\begin{array}{l}\text { KODE } \\
\text { GURU }\end{array}$} & \multirow{2}{*}{ MAPEL } & \multicolumn{16}{|c|}{ KOMPONEN ADM PEMBELAJARAN } & \multirow{2}{*}{$\mathrm{JMH}$} & \multirow{2}{*}{$\frac{\text { KELENGKAPAN }}{\text { ADM PBM (\%) }}$} \\
\hline & & & 1 & 2 & 3 & 4 & 5 & 6 & 7 & 8 & 9 & 10 & 11 & 12 & 13 & 14 & 15 & 16 & & \\
\hline 1 & A & BHS. INNGRIS & 1 & 1 & 1 & 1 & 0 & 1 & 1 & 1 & 1 & 1 & 0 & 0 & 0 & 0 & 0 & 0 & 9 & 56.25 \\
\hline 2 & $\mathrm{~B}$ & BHS. INNGRIS & 1 & 1 & 1 & 1 & 1 & 1 & 1 & 1 & 0 & 0 & 1 & 1 & 0 & 0 & 0 & 0 & 10 & 62.5 \\
\hline 3 & $\mathrm{C}$ & PKN & 1 & 1 & 1 & 1 & 0 & 1 & 1 & 0 & 0 & 1 & 0 & 0 & 0 & 0 & 0 & 0 & 7 & 43.75 \\
\hline 4 & D & IPA & 1 & 1 & 1 & 1 & 1 & 1 & 1 & 1 & 1 & 1 & 0 & 1 & 0 & 0 & 1 & 0 & 12 & 75 \\
\hline 5 & $E$ & BHS INDO, PKN & 1 & 1 & 1 & 1 & 0 & 1 & 0 & 1 & 0 & 0 & 1 & 1 & 0 & 0 & 0 & 0 & 8 & 50 \\
\hline 6 & $\mathrm{~F}$ & IPA & 1 & 1 & 1 & 1 & 0 & 1 & 1 & 0 & 0 & 0 & 0 & 1 & 0 & 0 & 0 & 0 & 7 & 43.75 \\
\hline 7 & G & IPS & 1 & 1 & 1 & 1 & 1 & 1 & 1 & 1 & 0 & 0 & 1 & 0 & 0 & 0 & 0 & 0 & 9 & 56.25 \\
\hline 8 & $\mathrm{H}$ & IPS & 1 & 1 & 1 & 1 & 0 & 1 & 1 & 0 & 0 & 0 & 0 & 1 & 0 & 0 & 0 & 0 & 7 & 43.75 \\
\hline 9 & 1 & PENJASKES & 1 & 1 & 1 & 1 & 0 & 1 & 0 & 1 & 0 & 0 & 0 & 0 & 0 & 0 & 0 & 0 & 6 & 37.5 \\
\hline 10 & $\mathrm{~J}$ & BHS. INDONESIA & 1 & 1 & 1 & 1 & 0 & 1 & 1 & 1 & 0 & 1 & 0 & 0 & 0 & 0 & 0 & 0 & 8 & 50 \\
\hline 11 & K & TIK & 1 & 1 & 1 & 1 & 1 & 1 & 1 & 0 & 0 & 1 & 1 & 1 & 0 & 0 & 0 & 0 & 10 & 62.5 \\
\hline 12 & $\mathrm{~L}$ & SBK & 1 & 1 & 1 & 1 & 0 & 1 & 1 & 1 & 1 & 1 & 1 & 0 & 0 & 0 & 0 & 0 & 10 & 62.5 \\
\hline 13 & M & MATEMATIKA & 13 & 13 & 13 & 13 & 4 & 13 & 10 & 8 & 3 & 7 & 6 & 7 & 0 & 0 & 1 & 0 & 111 & 693.75 \\
\hline \multicolumn{3}{|c|}{ Jumlah } & 100 & 100 & 100 & 100 & 30.8 & 100 & 76.9 & 61.5 & 23.1 & 53.8 & 46.2 & 53.8 & 0 & 0 & 7.69 & 0 & 53.37 & 53.37 \\
\hline
\end{tabular}

1 Jadwal tatap Muka

2 Analisis Kalender Pendidikan

3 Pengembangan Silabus

4 Pemetaan SK_KD

5 Analisis KKM

6 Program Tahunan

7 Program Semester

8 Pengembangan RPP
9 Daftar Hadir Siswa

10 Buku Batas Pelajaran

11 Kisi-Kisi UH, UTS,dan US

12 Kumpulasn Soal UH,UTS, US dan UASBN

13 Analisis Hasil Ulangan Harian

14 Program Remedi/Pemgayaan

15 Daftar Nilai

16 Bank Soal 
yang harus dimiliki oleh seorang guru, kedua yang bersangkutan belum lancar menggunakan computer utamanya dalam membuat dokumen dalam bentuk kolom, dan penyebab lainnya yang bersangkutan masih belum begitu paham cara menyusun administrasi pembelajaran tersebut sehingga menjadi lambat dalam mengerjakannya. Atau mungkin juga karena yang bersangkutan tidak meluangkan waktu untuk fokus pada penyelesaian tugas tersebut.

Selanjutnya dari tabel terlihat RPP (Rencana Pelaksanaan Pembelajaran) hanya $61,50 \%$. Padahal dokumen RPP adalah jantungnya proses pengajaran. Berdasarkan obervasi dan tanya jawab, penyebabnya adalah guru terbiasa masuk mengajar hanya dengan bermodalkan buku paket, LKS dan sejenisnya. Umumnya guru pada madrasah tersebut belum terbiasa mengajar dengan mengacu pada RPP. Sebagai akibatnya proses pengajaran tidak terarah dan terstruktur dengan baik.

Disisi lain terdapat komponen administrasi pengajaran yang sama sekali tidak dibuat oleh guru atau dapat dikatakan
ketercapaiannya
0\%.Komponen yang dimaksud adalah komponen Analisis Ulangan Harian, Pelaksanaan Remedial/Pengayaan dan Bank soal.

Secara umum, pada siklus 1 ketercapaian guru dalam menyusun administrasi pembelajaran 53,37\%. Sehingga perlu dilakukan tindak lanjut terhadap kegiatan In-House Training tersebut karena indicator keberhasilan In-House Training ini adalah $100 \%$ Guru berhasil menyelesaikan penyusunan administrasi pengajaran.

Setelah dilakukan refleksi terhadap siklus 1 ternyata ada dua hal yang perlu mendapat perhatian sebagai tindak lanjut yaitu:

1. Persentase Guru yang menyelesaikan administrasi pembelajaran belum mencapai $100 \%$

2. Administrasi pembelajaran yang telah disusun oleh guru ternyata masih belum sepenuhnya sesuai dengan panduan/pedoman sehingga masih perlu penyempurnaan.

\section{B. Hasil pada Siklus 2.}

Pada siklus 2, In-House Training dilakukan untuk menyempurnakan hasil yang 
diperoleh pada siklus 1 karena setelah dilakukan refleksi ternyata 
Tabel 7. Hasil In-Houe Training Siklus 2

\begin{tabular}{|c|c|c|c|c|c|c|c|c|c|c|c|c|c|c|c|c|c|c|c|c|}
\hline \multirow{2}{*}{ No } & \multirow{2}{*}{$\begin{array}{l}\text { KODE } \\
\text { GURU }\end{array}$} & \multirow{2}{*}{ MAPEL } & \multicolumn{16}{|c|}{ KOMPONEN ADM PEMBELAJARAN } & \multirow{2}{*}{ JMH } & \multirow{2}{*}{$\begin{array}{l}\text { KELENGKAPAN } \\
\text { ADM PBM (\%) }\end{array}$} \\
\hline & & & 1 & 2 & 3 & 4 & 5 & 6 & 7 & 8 & 9 & 10 & 11 & 12 & 13 & 14 & 15 & 16 & & \\
\hline 1 & $\mathrm{~A}$ & BHS. INNGRIS & 1 & 1 & 1 & 1 & 1 & 1 & 1 & 1 & 1 & 1 & 0 & 0 & 1 & 1 & 1 & 1 & 14 & 87.5 \\
\hline 2 & $B$ & BHS. INNGRIS & 1 & 1 & 1 & 1 & 1 & 1 & 0 & 0 & 1 & 1 & 1 & 1 & 1 & 1 & 1 & 1 & 14 & 87.5 \\
\hline 3 & $C$ & PKN & 1 & 1 & 1 & 1 & 1 & 1 & 1 & 1 & 1 & 1 & 1 & 1 & 1 & 1 & 1 & 1 & 16 & 100 \\
\hline 4 & $\mathrm{D}$ & IPA & 1 & 1 & 1 & 1 & 1 & 1 & 1 & 0 & 1 & 1 & 0 & 0 & 1 & 1 & 1 & 1 & 13 & 81.25 \\
\hline 5 & $E$ & BHS INDO, PKN & 1 & 1 & 1 & 1 & 1 & 1 & 1 & 1 & 1 & 1 & 0 & 1 & 1 & 1 & 1 & 1 & 15 & 93.75 \\
\hline 6 & $\mathrm{~F}$ & IPA & 1 & 1 & 1 & 1 & 1 & 1 & 0 & 1 & 1 & 1 & 1 & 1 & 1 & 1 & 1 & 1 & 15 & 93.75 \\
\hline 7 & G & IPS & 1 & 1 & 1 & 1 & 1 & 1 & 1 & 0 & 1 & 1 & 1 & 1 & 1 & 1 & 1 & 1 & 15 & 93.75 \\
\hline 8 & $\mathrm{H}$ & IPS & 1 & 1 & 1 & 1 & 1 & 1 & 1 & 1 & 1 & 1 & 1 & 1 & 1 & 1 & 1 & 1 & 16 & 100 \\
\hline 9 & 1 & PENJASKES & 1 & 1 & 1 & 1 & 1 & 1 & 1 & 1 & 1 & 1 & 1 & 1 & 1 & 1 & 1 & 1 & 16 & 100 \\
\hline 10 & J & BHS. INDONESIA & 1 & 1 & 1 & 1 & 1 & 1 & 0 & 1 & 1 & 1 & 1 & 1 & 1 & 1 & 1 & 1 & 15 & 93.75 \\
\hline 11 & $\mathrm{~K}$ & TIK & 1 & 1 & 1 & 1 & 1 & 1 & 1 & 1 & 1 & 1 & 1 & 0 & 1 & 1 & 1 & 1 & 15 & 93.75 \\
\hline 12 & $\mathrm{~L}$ & SBK & 1 & 1 & 1 & 1 & 1 & 1 & 1 & 0 & 1 & 1 & 1 & 1 & 1 & 1 & 1 & 1 & 15 & 93.75 \\
\hline 13 & M & MATEMATIKA & 1 & 1 & 1 & 1 & 1 & 1 & 1 & 1 & 1 & 1 & 1 & 0 & 1 & 1 & 1 & 1 & 15 & 93.75 \\
\hline & & Jumlah & 13 & 13 & 13 & 13 & 13 & 13 & 10 & 9 & 13 & 13 & 10 & 9 & 13 & 13 & 13 & 13 & 194 & 1212.5 \\
\hline & & Persentase & 100 & 100 & 100 & 100 & 100 & 100 & 76.9 & 69.2 & 100 & 100 & 76.9 & 69.2 & 100 & 100 & 100 & 100 & 93.27 & 93.27 \\
\hline
\end{tabular}

\section{KETERANGAN KOMPONEN ADM PEMBELAJARAN}

1 Jadwal tatap Muka

2 Analisis Kalender Pendidikan

3 Pengembangan Silabus

4 Pemetaan SK_KD

5 Analisis KKM

6 Program Tahunan

7 Program Semester

8 Pengembangan RPP
9 Daftar Hadir Siswa

10 Buku Batas Pelajaran

11 Kisi-Kisi UH, UTS, dan US

12 Kumpulasn Soal UH,UTS, US dan UASBN

13 Analisis Hasil Ulangan Harian

14 Program Remedi/Pemgayaan

15 Daftar Nilai

16 Bank Soal 
ada dua hal yang perlu ditingkatkan yaitu:

1. Persentase guru yang menyelesaikan administrasi pembelajaran belum mencapai $100 \%$

2. Administrasi pembelajaran yang telah disusun oleh guru ternyata masih belum sepenuhnya sesuai dengan yang diharapkan yaitu masih perlu penyempurnaan.

Guru telah meningkat kemampuannya dalam menyusun administrasi pembelajaran hal tersebut dapat dilihat dari prosentase administrasi pembelajaran yang diselesaikan pada siklus 1 dan dibandingkan dengan prosentase administrasi pembelajaran yang diselesaikan pada siklus 2 .

Setelah melalui In-House Training tahap 2 yang dilakukan pada tanggal 12 Februari 2019 dan diberi waktu selama 5 hari untuk menyelesaikan tugas penyusunan administrasi pembelajaran yang terdiri dari 13 komponen, diperoleh hasil bahwa telah terjadi peningkatan prosentase guru yang berhasil menyelesaikan penyusunan administrasi pembelajaran yaitu $53,37 \%$ menjadi $93,27 \%$ atau terjadi peningkatan sebesar 39,90\%.

Peningkatan terjadi pada hampir semua komponen administrasi pengajaran, mulai dari dokumen perencanaan yakni Analisis KKM, Program Semester, RPP, dokumen Penilaian, dan Dokumen Tindak Lanjur yakni Remedial dan Pengayaan.

Secara umum hampir seluruh guru telah menyusun administrasi pengajaran. Dari 16 Komponen administrasi Pengajaran 3 orang guru telah memenuhinya 100\% (16 komponen), 7 orang telah menyusun 15 komponen $(93,75 \%), \quad 2$ orang telah menyusun 14 komponen $(87,50 \%)$, dan hanya 1 orang yang menyusun 13 komponen saja $\quad(81,25 \%)$. Secara keseluruhan guru telah menyusun administrasi pengajaran dengan sangat baik.

Namun terdapat tiga (3) orang guru belum berhasil menyelesaikan keseluruhan administrasi pembelajaran yang ditargetkan utamanya pada komponen Program Semester dan Kisi-Kisi UH, demikian pula pada komponen RPP dan Kumpulan Soal-Soal, masih terdapat 4 orang guru yang belum menyusun dokumen tersebut. Menurut 
pengamatan penulis, alasan dari tidak tersusunnya dokumen tersebut disebabkan 2 orang guru tersebut belum menguasai keterampilan komputer sehingga dalam mengerjakan tugas tersebut sangat terhambat, 3 orang guru lainnya merasa waktu yang diberikan untuk menyelesaikan tugas masih perlu ditambah. Sedangkan dua orang lainnya memiliki waktu yang bersamaan dengan kegiatan madrasah lainnya sehingga tugas tersebut tidak terpenuhi dengan baik.Tindak lanjut dari siklus 2 adalah:

1. Peserta (guru) yang belum menguasai keterampilan komputer tersebut dilakukan mentoring dan diberi tambahan waktu untuk menyelesaikan penyusunan administrasi pembelajaran.

2. Peserta yang ada masalah berbenturan dengan tugas lainnya, diberi kebijakan berupa tambahan waktu untuk menyelesaikan penyusunan administrasi pembelajaran tersebut.

\section{KESIMPULAN}

Dari hasil penelitian dapat disimpulkan sebagai berikut:

1. Seluruh guru MTs INDOTEC Kendari menghendaki adanya
In-House Training penyusunan administrasi pembelajaran.

2. $100 \%$ guru memiliki motivasi yang tinggi untuk mengikuti InHouse Training dan memiliki keinginan yang kuat untuk membuat administrasi pembelajaran dan akan menggunakan administrasi pembelajaran tersebut sebagai penunjang proses pembelajaran.

3. Pada Siklus 1 terdapat $53,373 \%$ guru berhasil menyelesaikan penyusunan administrasi pembelajaran dan pada Siklus 2 terdapat 93,27\% guru berhasil menyelesaikan penyusunan administrasi pembelajaran.

4. Peningkatan kemampuan guru dalam menyusun administrasi pembelajaran sebesar 39,90\%

5. Untuk meningkatkan kemampuan guru MTs INDOTEC Kendari dalam menyusun administrasi pengajaran dapat dilakukan melalui kegiatan In-House Training.

\section{DAFTAR PUSTAKA}

BSNP. 2007. Model Rencana Pelaksanaan Pembelajaran Kurikulum Tingkat Satuan Pendidikan. Jakarta: Depdiknas.

Dadang Dahlan, In-House Training sebagai Sarana Peningkatan Kualitas Guru 
Tsanawiyah,

file.upi.edu/al.php

Dhony Firmansyah. 2008. Karya

Tulis disampaikan dalam

Pelatihan "Sukses Membuat

Proposal Penelitian yang

Bermutu"Kumiko Education

Centre.

Peraturan Pemerintah Republik

Indonesia Nomor 19 Tahun

2005 tentang Standar

Nasional Pendidikan

Undang-Undang Republik

Indonesia Nomor 14 Tahun

2005 tentang Guru dan

Dosen

Rahmat Saripudin, Tuesday, 28

October 2008 14:51,

Peningkatan Mutu

Pembelajaran. Media Kita.

Nurulfikri.sch.id/inde6.php

Undang - Undang Republik

Indonesia Nomor 20 Tahun

2003 tentang Sistem

Pendidikan

Nasional.http://rastodio.co

$\mathrm{m}$ /pendidikan/pengertian-

mengajar.html(diakses

tanggal 2 